\title{
Milena Kordić
}

\author{
EPISTEMOLOGIJA ARHITEKTONSKOG PROJEKTOVANJA \\ Od interdiskurzivne razmene znanja do projektantske strategije
}

APSTRAKT: Trasiranjem uticaja filozofskih teorija na arhitektonske, proširuje se mogućnost razvoja teorijskih osnova za formiranje novih projektantskih metodoloških modela. Ako kao savremeni kulturni kontekst pretpostavimo pomeraj u razumevanju sveta od determinisanog $i$ racionalnog ka multiplom, temporalnom i kompleksnom; (arhitektonsko) delovanje u takvoj realnosti pomera se od fiksnog i stabilnog ka novom balansu serija dinamičkih sistema u kojima uređenost i neuređenost pulsiraju jedno ka drugome kontinualno. Na konkretnom primeru rezonancije filozofskih ideja Žila Deleza u modelima promišljanja i stvaranja arhitekte i teoretičara Pitera Ajzenmana, identifikuju se transformacije postojećih i začetci novih metodoloških modela za projektovanje. Prepoznavanjem formativnih uslova postojećih modela, rad ukazuje na jedan od takozvanih otvorenih krajeva iz kog je moguć razvoj novih modela, u formi klice sa potencijalom za razvoj ka nepoznatom.

KLJUČNE REČI: modalitet promišljanja, modalitet stvaranja, interdiskurzivna razmena znanja, epistemologija projektovanja, projektantska strategija.

\section{Uvod}

Odnos modaliteta razmišljanja i modaliteta stvaranja u okviru arhitektonskog diskursa, fundamentalno je pitanje projektantskih metodologija. ${ }^{1}$ Iako se o odnosu arhitektonske teorije i prakse može posebno i opširno diskutovati, kao najteže ali i najizazovnije pitanje i za teoriju i za praksu ostaje: na koji način se (i da li u potpunosti) ideje ugrađuju u projekte i objekte arhitekture. U želji da se doprinese razumevanju mehanizama arhitektonskog projektovanja, ovaj rad proširuje domen metodologije na domen epistemologije projektovanja, ne bi li istražio složenost odnosa znanja i delanja u domenu arhitektonskog.

Projektovanje se oslanja na određenja saznanja (odnosno preduzima se u odnosu na određeni fundus znanja), ali istovremeno projektantski čin predstavlja iskorak iz poznatog ka nepoznatom kroz savladavanje seta nepodudarnih uslova života na koje arhitektura odgovara. Ovim iskorakom, projektovanje sopstvenim 
mehanizmima kreacije, dolazi do novih saznanja. Zato se u procesu istraživanja načina na koje se do znanja o projektovanju dolazi, ne sme izgubiti iz vida epistemološki kapacitet samog projektantskog postupka, tj mogućnost da projektovanje jeste jedna od epistemologija. U svetlu savremenih teorijskih postavki koje savladavaju pluralnost postmodernog konteksta, epistemologija projektovanja zahvata sadržaj metodologije arhitektonskog projektovanja. Imajući u vidu ovu dvosmernost $\mathrm{u}$ odnosu epistemologije i projektovanja ${ }^{2}$, epistemologija projektovanja se istražuje u polju preseka arhitektonskih i filozofskih teorija.

Savremeni arhitektonski kontekst čini divergentnost kulturnih diskursa, pa samim tim i divergentnost arhitektonskih ideja i projektantskih paradigmi. Zalaskom moderne, nestaje ambicija o natkriljujućoj arhitektonskoj ideologiji, metodologiji ili stilu, a divergentnost postmodernih teorijskih diskursa kulture dozvoljava, ali i obavezuje na - formulisanje misaonih osnova stvaralačkih praksi. U ovim okolnostima aktualizuje se pitanje odnosa arhitektonskog mišljenja i stvaranja, a posebno pitanje mogućnosti mišljenja kroz arhitektonski (stvaralački) diskurs. Budući da mišljenje po sebi pripada filozofiji, nameće se istraživanje odnosa arhitektonskog i filozofskog diskursa u cilju definisanja prelaza sa mišljenja $o$ arhitekturi na mišljenje kroz arhitekturu. Kroz istoriju filozofskog i arhitektonskog diskursa pojavljuju se preseci u kojima se pokazuju dobrobiti arhitektonskog interesovanja za filozofiju i filozofskog interesovanja za arhitekturu, koji konačno otvaraju pitanje postojanja izvorno arhitektonskog koncepta mišljenja. U odnosu na ovo pitanje, istražuje se mogućnost interdiskurzivne razmene znanja između filozofije i arhitekture.

Jedan od najvećih uticaja na projektantski diskurs u prošlom veku ostvaruje filozofska teorija Žila Deleza koja nudi novi ambijent za promatranje pomenute divergentnosti savremenog konteksta. Naime ova teorija nudi koncepciju u okviru koje je moguće promišljati načelnu simultanost, neodvojivost i međusobnu upletenost procesa, pa time i procesa mišljenja i stvaranja. Svojom složenošću predmetni odnos izmiče okvirima dijalektičkog promišljanja, koje mišljenje i stvaranje svrstava u odvojene kategorije da bi naknadno istraživala njihovu specifičnu dinamiku. Mnoštvenost i otvorenost procesa, upisanost u sebe sama kao i upisanost $u$ drugi proces neodvojiv a uslovljen, koje zahteva razumevanje projektantskih postupaka nude koncepti koje razvija Delez u okviru svoje filozofske platforme. Polarnu dispoziciju aktivnosti stvaranja i mišljenja (po kojoj su oni dve separatne, a ponekad i nasuprot postavljene kategorije) ova teorija zamenjuje savijutkom stvaranja-mišljenja u kojem je složenost i višeznačnost odnosa uočena i ohrabrena.

2 (gde postoji izvesno znanje o projektovanju ali i gde je projektovanje jedan od puteva da se do znanja dođe) 


\section{Struktura odnosa projektantskog znanja i projektantskog akta}

Da li postoji znanje i da li se ono može steći, pitanje je imanentno svakom naučnom istraživanju, bilo da ono sledi utvrđene istraživačke (naučne) metode ili ih preispituje u pokušaju da otkrije nove. Epistemologija kao grana filozofije koja proučava saznanje (njegovu prirodu, izvore, genezu i svrhu), obezbeđuje i svest o neuhvatljivosti sopstvenog predmeta istraživanja. Danas, sa bezmalo dvomilenijumskim iskustvom $\mathrm{u}$ ispitivanju šta znanje jeste, možemo reći da je sumnja u uspeh potrage koju izražava još Platon u svom delu Teetet ${ }^{3}$ (gde ostaje bez čvrstog odgovora nakon nekoliko pokušaja da odgovori na pitanje šta je znanje?) aktuelnija nego ikada i to zahvaljujući poslednjim rezultatima naučnih istraživanja. Parafrazirajući zaključke kvantnih fizičara, kroz usta - najspremnijeg teoretičara današnjice da prizna neuspehe teorije da dođe do jasnih odgovora - Slavoja Žižeka, možemo konačno reći: sad smo sigurni da ništa ne znamo. ${ }^{4}$ Ovde se Žižek oslanja na činjenicu da nauka u pokušajima da dođe do jasne slike, ili istine o svetu čiji smo deo, zalazi u polje koje izmiče saznajnim kapacitetima čoveka. Formule kojima opisujemo "objektivnu" realnost, i koje "rade" na matematičkom planu ${ }^{5}$, nisu prevodive u univerzum značenja, opiru se simbolizaciji i nepojmljive su iz perspektive iskustva svakodnevne realnosti. ${ }^{6}$

Da li postoji objektivna realnost o svetu za koju čovek nema saznajne kapacitete? Da li je upravo nemogućnost da se pojmi stvarna srž realnosti konačna istina, ili realnosti nema van funkcionalne mašine gde je simbolička slika sveta samo opscena senka?

Koji god scenario izabrali, sigurno je samo da nema jedinstvenog i celovitog odgovora na pitanje istine a posledično i pitanje znanja (o njoj). Jedino je sigurno da se odgovor na pitanje šta je znanje? udaljava sa koje god mu se ravni približili i da zbog toga priznanje da realnost mora ostati nespoznata da bi se mogla živeti, postaje važna osnova za razvoj kreativnih disciplina. Umesto frustracije besmislom, ovo priznanje otvara mogućnost da se analitičke paradigme zamene kreativnim.

3 U Platonovom delu Teetet, Sokrat nakon nekoliko pokušaja da izvede definiciju znanja, izgovara: "Znanje, moj Teetete, ne može biti niti percepcija niti pravo shvaćanje spojeno s objašnjenjem" u: Platon, Teetet. (preveo Milivoj Sironić, Zagreb: Naprijed, 1979), 184.(210b).

4 Slavoj Žižek, Organi bez tela (Beograd: Centar za medije i komunikacije, 2012), 82.

5 Najnovija istraživanja u oblasti kvantne fizike pokazuju da verzija formule relativiteta u kojoj je Ajnštajn uveo konstantu (Ajnštajnova konstanta) opisuje realnost, ali eksperimenti pokazuju neslaganje u redu veličine, tako da se postavlja pitanje ograničenja racionalnih znanja za spoznavanje ispitivanih procesa

6 Žižek u predavanju Realnost Virtuelnog, održanog u Londonu decembra 2003. godine, govori o paradoksu univerzalnih istina. Slavoj Žižek, The Reality of the Virtual, snimljeno predavanje, http://www.youtube.com/watch?v=RnTQhIRcrno (pristupljeno 12.12.2013.) 
Lekcije kvantne fizike za kreativne discipline donose važno otkriće: da stvari nisu u potpunosti konstituisane $\mathrm{i}$ da je cela realnost upravo u onoj tački kojoj stalno prilazimo, ali u koju nikada ne stižemo. Naučno istraživanje kreće iz poznatog ka nepoznatom u okviru sopstvenih alata i tehnika kako eksperimentalnih tako i teorijskih. No kretanjem unutar oblasti poznatog teško je otkriti novo ili nepoznato. ${ }^{7}$ Otkrića se dešavaju u momentu odskoka u nepoznato, pa je projektovanje, kao jedan od postupaka koji udomljava ovaj odskok, moćan istraživački alat.

Teoretizovanjem (odnosno teorijskim razlaganjem) umetničkih (pa i arhitektonskih) artefakata, produbljujemo njihovo razumevanje. Istovremeno, proširujemo polje u okviru kog je moguće formulisanje novih akcija, odnosno ohrabrujemo kreativne reakcije na postojeće artefakte. Sa druge strane, važno je u ovom postupku biti svestan nemogućnosti da se u potpunosti prikaže, razloži i teorijski elaborira stvaralački akt, kao i njegov proizvod. To ne znači da od epistemologije kreativnih diskursa treba odustati, već naprotiv, iskoristiti ih kao epistemološke alternative ili putokaze do posebnih oblika znanja koja izmiču analitičkim i racionalističkim metodama. Budući da kreativne diskurse koristimo za prikupljanje znanja koja su nepristupačna racionalnom zaključivanju, arhitektura može biti razmatrana kao jedna od mogućnosti da se pokažu nesvesni mehanizmi za savladavanje sveukupne kontingentnosti savremenog života. ${ }^{8}$ Budući da je reč o znanjima koja izmiču svesnom i determinisanom, arhitektura nas poput snova, može naučiti sopstvenom nesvesnom. ${ }^{9}$ Podstrekivanje nizanja svesnih veza između projektantskog mišljenja i stvaranja, jedan je od načina da se opcrta nesvesno jer čini vidljivom ravan zahvaljujući kojoj te veze nastaju i opstaju.

Razumevanje sveta u kome se predmetni kreativni postupak realizuje, možda je najvažnije mesto za analizu njegove metodologije, jer omogućava uvid u kontekst na koji reaguje kompleksni stvaralački aparat. Prema filozofu Alanu Badjuu, savremeni svet komunikacija emituje univerzum sastavljen od diskonektovanih slika, napomena i komentara, čiji je jedini princip nekoherentnost. ${ }^{10}$ Iako naizgled pluralizam savremenog sveta daje mogućnost različitih mišljenja, za Badjua, ovde

7 U delu Menon, Platon zapisuje dijalog Menona i Sokrata u kojem govori o nemogućnosti da se otkrije ništa novo kretanjem u domenu poznatog.

8 Kroz arhitekturu društveni mehanizmi progovaraju nekad svesno i namerno, nekad subverzivno, ali psihoanalitičara Žižeka najviše zanima momenat kada nesvesni stvari koje znamo, to znanje osvešćujemo kroz arhitekturu. Videti opširnije u Žižek, Organi bez tela

9 Žižek daje primer staljinističkog neoklasicizma koji jasno oslikava hijerarhizovane fiksne odnose autoritarnog režima (koji jesu realni uslovi za život), dok važeća politička ideološka retorika čini sve da prikaže da je pojedinac taj koji vlada udružen sa jednakima i jednak u vlasti, bez hijerarhije i bez dogmatizma autokrate. Žižek, Organi bez tela, 129.

10 Alain Badiou. "The Desire for philosophy and the Contemporary World." Online Journal for Lacan.com: The Symptom, Issue 8, Winter 2007, http://www.lacan.com/badesire.html (pristupljeno avgusta 2013) 
se radi o izvesnom potkopavanju mogućnosti logičkog mišljenja. Mogućnost da se prevaziđe ovo ometanje logike, i priliku da se uspostave nove veze među nekoherentnim fragmentima, nude kreativni diskursi.

Teoretičari projektantskih diskursa upućuju na neuhvatljivost projektantskih metoda $^{11}$, kroz odvajanje posebne kategorije iskustvenog ili prećutnog znanja (tacit knowledge). Iskustveno znanje je vrsta znanja koje nije lako racionalno pojmiti i može biti ostvareno samo kroz praktikovanje u odgovarajućem kontekstu. Još sredinom prošlog veka ovaj oblik znanja nazvan je "znanje kako" ("to know how" ili znanje-kroz-delanje) i odvojen od eksplicitnog znanja pod nazivom "znanje da" ("to know that"). Britanski filozof Gilbert Rajl koristi mnoge primere da pojasni ovu vrstu znanja (poput plivanja, voženja bicikla ili učenja jezika) među kojima se našlo i projektovanje. Iako ne opisuje eksplicitno kako se jedna vrsta znanja koristi u ostvarivanju druge, Rajl navodi da kompleksni diskursi poput projektantskog, podrazumevaju prenos jednog oblika znanja u drugi. ${ }^{12}$

S obzirom da se preduzima samo kao totalitet (unijom znanja, veština, intuicije i želja) i u odnosu na totalitet (nepodudarnih uslova života), projektovanje je samo jedan od oblika napora da se razume svet čiji smo deo.

Mogućnost opisivanja i objašnjavanja epistemologije projektovanja treba odvojiti od determinisanosti i racionalnosti samog projektantskog postupka, ali spoznavanje prirode projektantskog metoda važno je za njegovo razumevanje. Za prirodu projektantskog postupka simptomatična je aporija kao neizbežni deo procesa projektovanja. Da bi savladao ovu fazu i proizveo nestereotipan dizajn, projektant mora da razvije izvesnu otpornost na ambivalentnost i konfliktnost uslova na koje odgovara. ${ }^{13} \mathrm{U}$ okviru opsežnih istraživanja kreativnog ponašanja, sredinom prošlog veka pojavljuju se psihološke teorije o kreativnom razmišljanju gde se mentalna rigidnost prepoznaje kao glavna prepreka kreativnosti ${ }^{14}$. U okviru njih, psiholozi prepoznaju na koji način se želja za sigurnošću i izvesnošću suprotstavlja razvoju novih ideja, što samo podržava odbacivanje sigurnosti i izvesnosti kao ciljeva metodologije arhitektonskog projektovanja.

U misaonoj klimi dvadesetog veka, nakon drugog svetskog rata, u kojoj jezik postaje fundamentalni problem filozofije, pitanja odnosa jezika i realnosti, kao i

11 Videti opširnije u Nigel Cross, Design Thinking (New York: Berg, 2011) i u Gilbert Ryle, The concept of Mind (London: Hutchinson, 1949).

12 Gilbert Ryle, The Concept of Mind (London: Hutchinson, 1949), 25.

13 Džon Kris Džouns zaključuje da kvalitet projektantskog rešenja zavisi od projektantove sposobnosti da toleriše paralelno postojanje opozitnih mogućnosti, a pri tom izbegne strah i blokadu razvoja projektantskog postupka. John Chris Jones, Design Methods (1970, 2nd ed. London: John Wiley \& Sons, 1992), 47.

14 Videti podrobnije u: Geoffrey Broadbent and Antony Ward, Design methods in architecture (London: Lund Humphries for the Architectural Association, 1969) 
uloge jezika u spoznaji te realnosti, predstavljaju se kao nezaobilazna. Pojava teorije koja prevazilazi pitanje jezika kao obrtnog momenta u tretiranju tradicionalnih filozofskih pitanja nudi mogućnost preispitivanja postojećih oslonaca i mogućnost njihove zamene. Udaljen od jezika, i još važnije, udaljen od aktuelne opsesije jezikom, Delez gotovo nenamerno izaziva jednu vrstu obnavljanja filozofije same ili bar pokušaja njene redefinicije. Izbegavajući područja u kojima je ontološko pitanje povezano sa jezikom, on nikada jezik ne posmatra kao fundamentalni problem. Pokušava da se odvoji i od formalizovanja sopstvene ontologije, a filozofiju problematizuje, odnosno vidi je kao mogućnost za postavljanje problema i pitanja. Na ovaj način Delezova pozicija uvodi uznemirenost i neuređenost u kontinuirani razvoj filozofskog diskursa, a otklanja zatvorenost i dovršenost kao nasleđene ciljeve filozofskog promišljanja.

Novouvedeni kvaliteti poput uznemirenosti, neuređenosti, otvorenosti i nedovršenosti, zahvaljujući ovom modelu promišljanja, postepeno menjaju status od problema koji treba savladati ka kreativnom potencijalu sa kojim se treba udružiti. Ovo prihvatanje otvorenosti koje donosi Delezova teorija, širi se i na druge teorijske diskurse u decenijama koje slede, na različite načine (poput uticaja čistih intenziteta u Delezovim predstavama stanja materijalnog sveta) no zadržavajući karakter nesigurnosti, zapitanosti i problematizovanja samih postavki našeg znanja. Pola veka kasnije, stanje uznemirenosti, koje ova teorija prepoznaje kao prirodno i produktivno, usuđujemo se reći da je konačno usvojeno i prihvaćeno kao konstitutivni element same realnosti, pa shodno tome i gradivni element našeg delovanja u njoj.

Žil Delez se 2007. godine našao na dvanaestom mestu najcitiranijih autora u istoriji društvenih nauka, ${ }^{15}$ pa je uticaj njegove filozofske platforme na razvoj modaliteta za promišljanje (savremene) realnosti neosporan. Posebno je važan uticaj rada ovog autora na teorijske diskurse van filozofije, pa se javlja potreba da se ovi uticaji objedine i identifikuju kroz razne studije, pa čak i nove edicije referentnih biblioteka koje posebno analiziraju promene nastale pod uticajem ove teorije u svim kulturnim diskursima.${ }^{16}$ Džon Rajhman, filozof čiji se rad odnosi i na oblasti umetnosti i arhitekture, tražeći opredeljujući atribut Delezove misli, zaključuje: "naravno da je čitava Delezova filozofija o vezama; na neki način, ona je gotovo umetnost višeznačnih stvari koje se drže na okupu disjunktivnom sintezom, logičkim veznicima koji prethode i koji nisu reducibilni na predviđanja ili ereducation.co.uk/405956.article (pristupljeno 10.10.2012.)

16 U novom milenijumu nastaje nova edicija pod nazivom Deleuze Connections, u izdanju Edinburgh University Press čiji je urednik Ian Buchanan, http://www.euppublishing.com/ series/delco, (pristupljeno 15.5.2013.) 
identifikacije. Takav je zbilja njegov princip selekcije i afirmacije: zadržava se ... samo ono što uvećava broj veza." ${ }^{17}$

U domenu arhitekture možemo pratiti veze koje ona ostvaruje sa pomenutom filozofskom teorijom od teorijskih analiza Delezovih koncepata u arhitektonskom kontekstu, do samih slika koncepata stvorenih procesom projektovanja ili arhitektonskom formom. No, pravo i najznačajnije nasleđe ovog modela promišljanja predstavlja tek principijelno izmicanje (ili zamenjivanje) tradicionalnih oslonaca projektantskih teorija i strategija.

\section{Mehanizmi interdiskurzivne razmene znanja: arhitektura i filozofija}

Bazirajući svoju teorijsku postavku na objedinjavanju znanja iz prirodnih nauka i njihovoj vezi sa filozofijom, Delez svoje napore postavlja u interdiskurzivnu perspektivu i time izaziva izvesno "obnavljanje" filozofije. Prati razvoj misaonih paradigmi u prirodnim naukama i pomeraje koje uvodi kvantna mehanika, gde objekti koji su bili nesagledivi u klasičnoj slici postaju vidljivi. Iskorak iz statične i konačne perspektive ka pejzažima nefiksiranosti koji je učinila fizika, Delez prevodi na sagledavanje realnosti i u okviru društvenih nauka. Posledica ovog iskoraka je postepeno gubljenje determinizma u svakom humanističkom diskursu.

Filozof i teoretičar arhitekture Džon Rajhman u knjizi Constructions nalazi da je najdragoceniji aspekt uticaja Delezovog rada na arhitekturu kroz polje filozofije arhitekture, na kom nudi pragmatizam za razliku od do tada dominantnih filozofskih ideja iz domena idealizma. ${ }^{18}$ Delezov predlog da se nanovo izgradi filozofija na osnovama eksperimentalnog empiricizma nudi napuštanje idealističkih ideja o građenju formi liberalnom ekspresijom (umetničkom ili ekspresijom genija), a razmišljanje postavlja u polje eksperimentalnog. Po njemu mišljenje pokušava da pronađe pukotine u postojećem terenu (filozofskim platformama) prepunom ograničenja gde tek zahvaljujući prevazilaženju tih ograničenja, mišljenje postaje eksperimentisanje a filozof eksperimentator. Za Deleza filozofija je invencija ili kreacija koncepata čija svrha nije da tačno reprezentuju kakve stvari jesu, nego da prizovu nove zemlje i nove ljude, kakvi još ne postoje. ${ }^{19} \mathrm{U}$ potrazi za novim ljudima i svetom nastaju novi koncepti, pojmovi i planovi. U knjizi Šta je filozofija? Delez i Gatari govore o nastanaku filozofije kao sinhronom kreiranju pojmova i plana imanencije. "Filozofija je u isto vreme stvaranje pojmova i uspostavljanje plana.

18 John Rajchman, Constructions (MIT Press, 1998), 18.

19 Delez i Gatari, Šta je filozofija?, 112. 
Pojam je početak filozofije, a plan je njeno zasnivanje."${ }^{20}$ Plan imanencije Delez postavlja kao nešto pretfilozofsko, koje "ne označava nešto unapred dato, već nešto što ne postoji izvan filozofije, iako ga ona pretpostavlja. To su njeni unutrašnji uslovi."21 Plan predstavlja osnovu na kojoj filozofija stvara svoje pojmove, ali koja se obraća i nefilozofima, koja još ne barata pojmovima i "povlači neku vrstu pipavog eksperimentisanja, a njegovo opcrtavanje pripada sredstvima koja se teško mogu opisati, sredstvima ne baš racionalnim i razboritim."22 Prema Delezu, da bi filozofija nastala, mora pretpostaviti ono što je izvan nje, kao što se ne može misliti a da se "ne postane nešto drugo, nešto što ne misli...koje se vraća u mišljenje i ponovo ga pokreće."23 Time ova filozofska postavka nudi mehanizam konstantne problematizacije kojim se postiže konzistencija mišljenja a da se ne izgubi beskonačno ${ }^{24}$ u koje je mišljenje uronjeno.

Kada projektantsko mišljenje stvara arhitektonske pojmove koji su drugo u odnosu na plan koji zauzimaju, omogućava se stalnost razvoja, promene i otvorenosti koji predstavljaju osnovne deluzijanske okvire za promišljanje. Delezova napomena da su pojmovi čvrsto povezani sa planom imanencije ali da nisu u prostom odnosu gde zbir pojmova čini plan, značajna je za uspostavljanje koncepta odnosa projektantskog promišljanja i stvaranja. Ukazivanje da pojmovi (pa i arhitektonski) iako su fragmentarne celine nisu uređeni na taj način da se uklapaju, oslobađaju mišljenje i delanje hijerarhizovanih dijalektičkih struktura. Iako pojmovi nastanjuju jedan plan, on "nije ni mišljen ni misliv pojam, već slika mišljenja, slika kojom predstavljamo značenje mišljenja, služenje mišljenjem, orjentisanje u mišljenju...". ${ }^{25}$ Filozofija arhitekture otvara mogućnost da se arhitektura misli kroz fragmentarne pojmove koji istovremeno sistemom odnosa formiraju plan koji naseljavaju a koji ipak ima dva lica: prirodno i mišljeno. ${ }^{26}$ Ako razumemo plan imanencije kao sliku mišljenja čija je druga strana priroda, onda pojmovi koje stvaramo i koji naseljavaju ovu ravan su rezultat istovremenosti mišljenog i prirodnog. Ova slika o beskonačnim kretanjima koja su sama u sebi sadržana i uvijena jedna u druge, prepoznatljiva je za arhitektonsko mišljenje zbog istovre-

Delez i Gatari, Šta je filozofija, 53.

21 Delez i Gatari, Šta je filozofija, 52.

22 Delez i Gatari, Šta je filozofija, 53.

23 Delez i Gatari, Šta je filozofija, 54.

24 Delez i Gatari, Šta je filozofija,48.

25 Delez i Gatari, Šta je filozofija, 47. Delez i Gatari tvrde da mišljenje zahteva beskonačno kretanje, ili kretanje beskonačnog, i da kretanje zahvata sve, to beskonačno kretanje koje "nikad ne ide ka nekom odredištu a da se nije vratilo u sebe" Ibid, 48.

"...pojavljuje se kao Priroda i kao Mišljenje, kao Psysis i kao Nous." Ibid. 49. 
menosti konkretnih i apstraktih uslova koje arhitektura savladava, kao i zbog nepodudarnosti kategorija na koje reaguje u proizvodnji sopstvenih strategija.

Delez razvija model za razumevanje kretanja koncepata između disciplina i to na primeru kreativnog čina na filmu (predavanje na konferenciji 1987. godine ${ }^{27}$ ), gde razvija i osnovne teze o kreativnosti, filozofiji i odnosu umetnosti i otpora. Zasnovano na ekstrahovanju čistih intenziteta iz konkretnih formi, koji se dalje mogu prenositi na nove i nove forme, kretanje koncepata između disciplina Delez komentariše kroz niz primera iz domena filmske umetnosti. Kretanje intenziteta naglašava kao mogućnost razmene koja nije trivijalizovana direktnim prenošenjem ili prevođenjem, već nudi koncept rezonance kao mehanizam prenošenja uticaja iz jednog domena mišljenja i stvaranja u obliku apstraktnog čistog intenziteta koji dalje izaziva pokret unutar tkiva drugog domena. Oscilacija intenziteta ideja iz jedne oblasti rasprostire se na fluks drugoga diskursa u kojem nastaje pokret/ vibracija koja dalje rađa varijacije tkiva i time razvijanje različitih konkretnih formi/procesa. Delez daje primer prenošenja ideja iz literature na film (i obrnuto), kojim ilustruje nemogućnost preuzmanja i primene ideja rođenih u jednom diskursu na drugi diskurs metodama analogije ili metafore. Kao gotova, konkretna forma ideja iz jedne oblasti ne može se uvesti kao uticaj na drugu oblast. Samo kao čist intenzitet, ona može da ostvari uticaj na tkivo drugog diskursa mobilišući njegove već nabijene potencijale za razvoj i vodeći ih ka formiranju sopstvenog autentičnog oblika. $^{28}$

Nivo na kome ideja u obliku intenziteta (iz literature ili bloka slika-vreme kako Delez naziva konstitutivni element filma) ima mogućnost da se kreće dalje, značajan je za razumevanje upliva drugih disciplina na polje arhitekture u poslednjih par decenija. Rezoniranje kao mehanizam prenošenja uticaja podrazumeva da se uticaj uvodi na materiju/tkivo diskursa izazivajući dalje njegovo kretanje koje rađa nove forme. Ideja ili koncept unutar diskursa se može stvoriti samo u odnosu na sredstva samog diskursa. $U$ istraživanom slučaju ideje iz filozofskog diskursa prepoznate u obliku intenziteta, kreću se ka oblasti arhitektonske teorije da bi $u$

Gilles Deleuze, What is the Creative Act?, Predavanje na konferenciji Conference donnee dans le cadre des "Mardis de la Fondation" (17. mart 1987), http://www.youtube.com/watch? $\mathrm{v}=7$ DskjRer95s (pristupljeno 22.5.2013.)

28 Delez opisuje kako ideje u filmu mogu biti samo filmske, no da postoje ideje u filmu koje rezoniraju (korespondiraju) sa idejama u literaturi. Taj događaj Delez naziva izvanrednim susretom. Opisuje konkretnu situaciju u kojoj čist intenzitet rezonira iz literarnog lika u filmski: gde likovi iz romana Dostojevskog stalno u nekoj krajnjoj nuždi u poslednjem trenutku, veoma agitirani, perpetualno obuzeti urgentnošću, iako su u stalnoj situaciji razrešenja pitanja života i smrti, postaju svesni postojanja drugog pitanja. Iako nisu sigurni koje je to pitanje, likovi se zaustavljaju znanjem da postoji urgentnije pitanje. U istom stanju su likovi Akira Kurosave na filmu, koji preuzimaju intenzitet ali ne i narativ, a tu situaciju Delez opisuje ne kao učenje Kurosave od Dostojevskog, već kao divan susret. 
odnosu na sredstva proizvođenja diskursa, nastale ideje o stvaranju arhitektonskog dela. Delez tvrdi da je svaka ideja nekog diskursa već operativna po sebi jer se rađa u odnosu na znanja o proizvodnji ili kreiranju unutar njega. $U$ ovoj tvrdnji rad vidi izazovnu tezu da o diskursu mogu misliti (ili govoriti) samo stvaraoci toga diskursa, što vodi ka preispitivanju mogućnosti da o teoriji arhitekture pišu nearhitekte. Ovo stanovište posebno je provokativno u savremenom kontekstu gde arhitektonsku teoriju pišu pre teoretičari drugih diskursa nego sami arhitekti. Simultanost mišljenja i stvaranja u kreativnim disciplinama nije nova tema, no slikovitost koju Delez nudi svojim pejzažima intenziteta, omogućava arhitekti da hrabro prisvoji mišljenje o arhitekturi kroz direktno iskustvo proizvođenja (direktno uključivanje u fluks tkiva arhitektonskog diskursa), a ne sa objektivizirane racionalizovane distance.

Delezovo viđenje filozofije kao kreativne discipline ${ }^{29}$ koja formuliše koncepte a ne opisuje stanja, nudi još jednu za arhitekturu, važnu postavku. To je horizontalna rizomska struktura u okviru koje se razvija naše promišljanje, koja zamenjuje klasičnu hijerarhijsku strukturu po kojoj je filozofija (meta-nauka) natkriljujuća platforma svih ostalih nauka pa i umetnosti. Po rizomskoj strukturi, ideje u filozofiji rezoniraju sa idejama u arhitekturi, nevidljivim i neuhvatljivim fluktuiranjima intenziteta koji ipak dovode do izvanrednih susreta. Nedeterminisanost i nestrukturiranost odnosa filozofije i arhitekture, o kojoj govore Ljiljana Blagojević (arhitektura nije ilustracija filozofskih teorija) ${ }^{30}$ i Mark Rigli (niti se iz arhitektonskih intuicija naknadno čitaju filozofske teorijske matrice), ${ }^{31}$ pokretačka su snaga dinamike ovog odnosa. Na osnovu delezovskog modela rezoniranja ideja, izlaganje znanjima iz drugih diskursa može proširiti rasprostiranje uticaja intenziteta tih znanja do te mere - da nastupi neuhvatljivi momenat konstruisanja ideje u oblasti matičnoga diskursa. U ovom modelu delezovska misao pokazuje svoju materijalističku prirodu (bivajući direktno operativna) jer nudi polje za intervenciju umesto polja za refleksiju. Ova operativnost je, između ostalog, čini plodnim poljem za promišljanje arhitektonskog diskursa. Sa druge strane, pitanja koja postavljamo o arhitekturi, simultano su filozofska, jer pitanje mišljenja ima ugrađene alate filozofskog diskursa. U ideju o arhitekturi već je ugrađena ona sama, zato nije prenosiva, već može samo da se rezonira.

U knjizi Šta je filozofija? Delez i Gatari označavaju svet kao sveprotegnuti haos kroz koji filozofija i ostali diskursi prave svoje preseke. Te ravni preseka neograničene su, a protežu se isključivo putem veza u stalnom kontaktu materije,

29 Delez i Gatari, Šta je filozofija, 70.

30 Ljiljana Blagojević, "Dekonstruktivistička arhitektura n'existe pas" u Glas i pismo, Žak Derida $u$ odjecima, Petar Bojanić, ed. (Beograd: Disput, Institut za filozofiju i društvenu teoriju, 2005.), 89-97: 90. 
vodeći procese od poznatih ka stalno nepoznatim formama. Čitava filozofska postavka obeshrabruje svaki unificiran plan organizacije ili razvoja i samim stilom kojim formuliše ideje u vidu serija i platoa koji se uvek granaju i jedni na druge nadovezuju (čistim kontaktima) bez zatvaranja u konačan hijerarhizovan sistem mišljenja. Delez pišući o protezanju i kretanju sveukupne materije uvodi pojam konektivnosti (connectivity) ${ }^{32}$ koji omogućava kretanje konstantnim tokom, putem prelaza iz jedne singularne tačke u drugu, neposrednim kontaktom. U cilju istraživanja odnosa filozofije i arhitekture, možemo istaći da ova teorija sama nudi alibi za upotrebljavanje filozofije od strane drugih diskursa, na osnovu kojeg pronalazimo mesto dodira filozofskih i arhitektonskih teorija sa ciljem identifikovanja novog otvorenog kraja rizomske strukture koji nudi klicu razvoja novih odnosa arhitektonskog promišljanja i stvaranja.

Delez zadatkom filozofije smatra njeno kretanje u mnogo pravaca odjednom, upravo da bi otvorila nepredvidive veze između disciplina. ${ }^{33}$ Kada piše o drugim filozofskim idejama, Delez koristi metodu koju naziva filozofskom sodomijom, (burggery) jer progovara iz usta autora o kojem piše - sopstvenim jezikom. Preduslov da se ova metoda realizuje je potpuna povezanost, odnosno čista konektivnost. Tek razumevajući u potpunosti filozofije o kojima govori, našavši se $n a$ mestu onoga koji je zagovara, Delez biva u stanju da u nju ugradi sopstvene, različite, a nadovezane ideje. Govoreći o idejama svojih prethodnika, u samo razumevanje tih ideja on ugrađuje svoje stavove i tek u ovom stanju nadovezivanja a ipak diferencijacije, otvara nove. Ispitivana filozofska platforma nudi prostor za mislioce čiji identiteti nisu zaokruženi i očvrsnuti oko definicija hijerarhizovanih i zatvorenih sistema. Upravo u kapacitetu za rad sa neuređenostima i neodređenostima rad vidi produktivnost razmene znanja predmetne filozofske platforme i kreativnih diskursa. Delez razvija pre osećaj za logiku, nego racionalnu logiku koju nastavlja filozofija tradicionalno i time nastoji da pokaže da osim logike smisla, postoje zone nedeterminisanosti koje uvek prate organizacione forme. Upravo ove zone su važne za mišljenje jer razmišljati, po Delezu, znači eksperimentisati - a ne suditi. Zanima ga sve ono što društvo još uvek nije prepoznalo i odredilo kao poznato i stabilno, pa zahvaljujući baziranosti na pomenutom osećaju za nepoznato umesto na racionalnoj logici, emancipacija ove teorije u prošlom veku značajno je ojačala ulogu kreativnih diskursa u razvoju društva.

Delezova teorija nudi generalno pravilo po kome je potrebno polazeći od datih objekata i stanja otvarati nove putanje za transformaciju. Ovaj gotovo empirijski princip Delez pronalazi još kod filozofa skeptičara Dejvida Hjuma, razumevajući 
da su "odnosi spoljašnji sopstvenim uslovima"34, tvrdeći da upravo Hjum anticipira jedan novi tip mislioca-eksperimentatora koji je spreman da pređe granice zdravog razuma $\mathrm{i}$ da kuje relacije $\mathrm{i}$ veze van polja poznatog. Poštovanjem principa za uspostavljanje veza putem zamenjivanja sigurnosti verovanjem u nesigurnost, podržava se uverenje u postojanje uvek novih veza. Zato Rajhman kaže: moramo stvarati veze, stalno sve više veza, ${ }^{35} \mathrm{za}$ šta nije potrebno znanje (ni sigurnost, čak ni ontologija) već vera da će nešto novo naići, iako nismo potpuno sigurni šta je to. Budući da je filozofija ta koja konfrontira nove probleme i otkriva nove orjentacije, Delez otkriva novi problem koji nastaje u 19. veku a aktuelan je i u 20. - problem odsustva novih veza. Svaka prosta i neaktivna klasifikacija znanja poput enciklopedija, svrstava se u pomenut problem, pa Delez ističe ulogu umetnosti u njegovom prevazilaženju, posebno ulogu moderne umetnosti koja predstavlja borbu da se oslobodi čist doživljaj od klišea ili uproštavanja mogućnosti. Kreativni diskursi tako dobijaju ulogu vodiča u skoku iz poznatog u nepoznato, a čitava slika sveta menja se drastično, prelaskom sa one koja je izgrađena na stabilnim kategorijama na onu koja počiva na dinamičnosti međusobno formativnih veza (interkonekcija).

Odskok koji se ovim radom želi naglasiti, koji je u filozofiji svojom teorijom načinio Žil Delez, odnosi se upravo na preokret u razumevanju uslova konteksta i reagovanju na njegovu narastajuću raznovrsnost, koji se u projektantskim teorijama kraja prošlog i početkom ovog veka pokazuje u konstantnoj razgradnji i nestajanju tipologija kao čvrstih kategorija. Funkcionalizam kao podskup modernizma sa stanovišta tehnike i proizvodnje prepoznao je neophodne fizičke parametre prostora za stanovanje, pa su se kroz kvalitet parametara kao što su veličina stana, osvetljenost, struktura, organizacija, fleksibilnost, infrastruktura, formirali određeni standardi koji predstavljaju minimum, optimum ili maksimum uslova za život. Funkcionalizam je na ovaj način izostavljao emocionalni odnos korisnika i stambenog prostora koji predstavlja dom, redukujući složenost (filozofskog) koncepta stanovanja na utilitarnost koju pomenuti fizički okvir nudi. Teorijska svest o raslojavanju kompleksne strukture simbola, snova, ideala i aspiracija koju specifičan korisnik u okviru sopstvenog socio-kulturnog i urbanog identiteta ostvaruje ne bi li materijalni prostor imenovao domom, razvija se i pod uticajem zahteva postmodernih diskursa za kompleksnošću. Delezova pozicija potrage za usložnjavanjem je radikalna jer tvrdi da svaki postupak svođenja, ili redukovanja, predstavlja udaljavanje od otkrivanja prave prirode izučavanog. Da postoji jasan i precizan algoritam za prevođenje čovekovih ideja u materijalni prostor okruženja, postojala bi samo jedna i konačna teorija i metodologija arhitekture. Ultimativni doprinos uticaja Delezove filozofije na arhitektonski diskurs je konačno prihvatanje neizves- 
nosti i neprebrojivosti u koncipiranju pa i proizvođenju arhitektonske materijalne realnosti.

U kartezijanskoj stabilnoj slici kojoj se opire Delez, postoje jasno koordinisani delovi i jasna hijerarhija tih delova, pa time i hijerarhija značenja i istina u sistemu mišljenja. ${ }^{36}$ Istina $\mathrm{i}$ vrednosti su prema ovom sistemu apstraktne, transcediraju realnost i zahteve svakog pojedinačnog događaja, a nalaze se u stepenu višeg autoriteta od koga niži (jedinica, deo) dobija uputstvo o praćenju utvrđene putanje. Rezultat ovog sistema je masovna redukcija potencijala i mogućnosti. Rigidnost ovakvih sistema Delez naziva diktatorskim, jer se subjektivnost gradi u oslanjanju na pre-postojanje fiksne istine. Svako ispitivanje pristupa fiksnoj istini, pa makar to bilo i nesvesno (po psihoanalitičkim teorijama), Delez vidi kao odustajanje od daljih projekcija ka novim mogućnostima. Moment u kome subjekt stupa u odnos sa objektom da bi ga razumeo i reprezentovao, je momenat dodira gde se nove veze uspostavljaju povratno menjajući početno stanje i subjekta i objekta. Ovim stvaranjem povratnih veza - interkonekcija kako ih naziva Delez, nastaje novi sklop (asemblaž) u događaju, uključenosti i invenciji. Ne postoji dalja svrha ovih interkonekcija niti njihovo jedinstvo na višem nivou, one jednostavno dopuštaju postajanje. ${ }^{37}$ Kao osnova principa kontinuiteta interkonekcije omogućavaju novu strukturu mišljenja koju Delez i Gatari nazivaju rizomskom. U doslovnom (botaničkom) smislu rizom je tip granjanja (stabla) koje se širi ispod zemlje horizontalno, puštajući korenje i nove klice, ne iz jednog jedinstvenog jezgra, već iz mreže koja se širi beskonačno iz svake od svojih tačaka. ${ }^{38}$ Kod rizomatične strukture, multiplicitet nije konačni proizvod grananja kao kod stabla, već sama priroda strukture. Decentriranost i nehijerarhizovanost mreže su u osnovi rizoma i stoga on kao model odgovara heterogenosti. Sačinjen od nasumičnog preseka bezbrojnih linija rizom povezuje naizgled odvojene impulse i sile, one koje ne samo da su različite nego su naizgled u sasvim drugim kategorijama. Ono što rizomatičnu strukturu odvaja od svih hijerarhizovanih struktura je sistemska otvorenost. Otvorenost je neosporen Delezov motiv koji ostaje i nakon svih daljih čitanja i kritika njegovih postavki, na čijoj liniji savremeni filozofi i danas postavljaju nove platforme, ${ }^{39}$ a na kojoj i ova studija traži ključ za razumevanje i dalje razvijanje koncepcija arhitektonskog projektovanja.

36 Delez opisuje stabilni model razmišljanja kao model stabla, po kome je suština uvek van entiteta u stepenu višeg autoriteta od onog koji sam deo poseduje. Videti u: Deleuze and Guattari, A Thousand Plateaus, 16.

37 Deleuze and Guattari, A Thousand Plateaus, 10.

38 Deleuze and Guattari, $A$ Thousand Plateaus, 6.

39 Jedan od najistaknutijih aktuelnih kritičara Žila Deleza - Alan Badju, iako sasvim drugim sredstvima zagovara isti cilj: ultimativnu otvorenost sistema mišljenja. Videti opširnije u: Alain Badiou, Deleuze: The Clamor of Being 
Uticaj načelnog otklona od determinizma $\mathrm{u}$ teoriji kulture na projektantsku poziciju najpre se pokazuje na metodološkom planu. Odustajanje od potrage za definicijama i klasifikacijama u projektantskom postupku vodi ka okretanju pitanjima umesto odgovorima. Bazirajući se na pitanjima, projektantski postupak otkriva moćnija kreativna oružja od odgovora. Na taj način, pojavljuje se mogućnost da se dalji razvoj projektantskih paradigmi otkoči izmicanjem tradicionalno razvijanih fundamenata discipline, a da se sam postupak izmicanja ili izmeštanja preispita kao savremena epistemološka metoda arhitektonskog diskursa.

Kreativnim diskursima, nerešenost ili čak nerešivost fundamentalnog pitanja epistemologije: šta je znanje? o kojoj je bilo reči u prvom poglavlju, donosi bolju poziciju u teorijskim raspravama. Budući da ne postoji konsenzus oko toga šta znanje jeste ${ }^{40}$ same sumnje o osnovnoj definiciji, izvorima i svrsi ljudskog znanja tvore istraživački proses, koji projektovanje sprovodi kroz sopstvene alate postajući tako jednom od epistemologija. Za projektovanje je odustajanje od fiksnih definicija ključno, jer se njime dozvoljava istraživanje znanja bez odgovora na fundamentalno pitanje šta ono jeste. Istraživanja po pitanjima kako se znanje stiče i šta mu je svrha, kako konstruišemo koncepte u sopstvenom umu, odnos između onoga što "znamo" i objekta našeg znanja, pouzdanost naših čula i tome slično, dovoljna su za opcrtavanje polja istraživanja, bez njegovog fiksiranja, određivanja i definisanja. Kao ključnu karakteristiku odnosa filozofije i arhitekture ponavljamo tezu iz prethodnog poglavlja o Delezovom zapažanju da mišljenje o (svakom diskursu, pa i) arhitekturi pripada (njemu samom) arhitekturi, a da filozofiji pripada iznalaženje koncepata u okviru kojih se to mišljenje razvija. Na ovaj način može se reći da iznalaženje koncepata u filozofiji proširuje prostor za rad u oblasti arhitekture.

Prateći prostor za promišljanje koji proširuje Delez, na planu arhitektonskog projektovanja, istražujući oslonce za delovanje (koji se nalaze u znanju) dolazimo do dva metodološka pristupa u samom razumevanju realnosti, a posledično i u delovanju prema njoj. Ako bi esencijalističkom viđenju sveta ${ }^{41}$ odgovarala redukcija kao metod, Delezovom svetu multipliciteta i singulariteta odgovara diferencijacija. Na planu samih arhitektonskih strategija ova nijansa čini svu razliku između alata i tehnika za projektovanje razvijanih pre i zaključno sa modernizmom, i alata i tehnika razvijanih nakon modernizma do aktuelnog trenutka.

40 Prvu teoriju znanja plasira Platon u Teetetu, a poznajemo je pod nazivom tripartidna teorija znanja. Ona tvrdi da je znanje oslonjeno na tri pojma: Uverenje, Istinu i Opravdanost. Definisano kao Opravdano istinito uverenje, znanje je istraživano u mnogim filozofskim postavkama, koje su ovo polazište opovrgavale ili se na njega naslanjale.

41 Viđenje sveta koje predstavlja Parmenidov ontološki odgovor (da li postoji išta?), da ako išta postoji to mora biti jedno, nepromenljivo i trajno biće, i samim tim ono mora biti nedeljivo, statično i večno, dok su sva kretanja i postajanja samo privid usled nesavršenosti naše percepcije. 
U periodu konstituisanja i dominacije modernizma u arhitekturi, usavršavali su se i favorizovali alati i tehnike za projektovanje koji su identifikovali sličnosti (takozvane univerzalnosti) u okviru ljudskih potreba, aktivnosti i prostornih distribucija. Pronalaženje univerzalnih kategorija vodilo je ka generisanju fiksnih tipova arhitektonskog prostora (organizacije, a posledično i forme) koji odgovaraju prethodno fiksiranim aktivnostima u njemu. Ovo očvršćavanje oko sličnosti odnosno "tipova", vodilo je ka formulisanju standardnih problema i standardnih rešenja. Kritikujući zatečeno, postmoderna teorija pre svega slavi razlike i subjektivne perspektive, mikronarative i specifikume svih fenomena koje je moderna generalizovala. Kritikuje i logocentričnu tradiciju, stavljanje na pijedestal pojma napredka $\mathrm{i}$ isecanje iz istorijskih procesa, čime vraća u fokus promišljanja pojam slobode. Arhitektonska teorija poslednjih pola veka traži svoj autentični put u ispitivanjima pojma slobode na kom podnosi veliko breme redefinicije odnosa etike, estetike i tehnike. Ovo breme slobode mali broj arhitekata uspeva da ponese, no zahvaljujući njima, stvara se klima u kojoj (polako, ka kraju dvadesetog veka) teškoće oslobađanja ubiraju svoje prve plodove u iskoracima arhitekture ka drugim diskursima - umetnosti, filozofiji i nauci. Iz prirodnih nauka u filozofiju i teoriju kulture prvenstveno ulazi Ajnštajnova teorija relativiteta, koja raskida sa sveobuhvatnošću i kategorijalnošću Aristotelovog učenja. Na taj način stvara se osnova za gotovo eklektičko spajanje različitih subjektivističkih perspektiva i idejnih pravaca. Sve nominalno i totalitarno se odbacuje, kao i posredovanje između pojedinačnog, posebnog i opšteg. Neposredovano pojedinačno postaje dominantni izvor procesa saznanja, a pojedinac i razlika postižu status kulta. Apsolutizivana pojedinačna perspektiva donosi varljivu slobodu stvaralačkim diskursima, a neposrednost iskustva ukida distancu koju je moderna zahtevala zarad objektiviziranja (posmatranja) realnosti. Ovime se postepeno ukida i nezavisnost subjekta od objekta, čime se sama epistemologija relativizuje u uslovima lišavanja distance potrebne za objektivno sagledavanje "stvari". Istraživač, neodvojen od predmeta istraživanja čini da relativizam postane imanentan. Osim što se spasava opasnosti od neobjektivnosti, time što ukida kategoriju objektivne istine, ukidanjem distance subjekta od objekta teorijska platforma Žila Deleza gotovo obavezuje na uključivanje u svet umesto njegovog posmatranja, što i jeste izvorna pozicija kreativnih diskursa.

Otvaranje alternativnih oblika promišljanja koji se posvećuju upravo fragmentima sa svešću o njihovim mnoštvenostima, otvaraju mogućnosti da se projektantske strategije formulišu čak i u vidu slobodnih asocijacija na fragmente konteksta, budući da je jedinstvo iskustvene osnove legitimno ukinuto. Zamena kontinuiteta diskontinuitetom i celine njenim delom, otvara put ka zameni uzročnosti kontigentnošću. ${ }^{42}$ Kontingentnost viđena kao određena vrsta kreativne slobode, koja nas oslobađa pravilnih načina u odnosu na pretpostavljene objektivne istine, nastaje 
kao slučajno poklapanje individualnih opsesija sa zajedničkim potrebama.$^{43} \mathrm{Ima}$ li direktnijeg poziva na subjektivnu akciju u ime objektivnog dobra, što za arhitekte poslednjih pola veka otvara mogućnost da istraživanjem introvertnih, hermetičnih želja i misli zapravo otvore mogućnosti da društvo promeni oblik razumevanja arhitekture, nauke i umetnosti.

\section{Rezonancija ideja Žila Deleza u domenu epistemologije projektovanja Pitera Ajzenmana}

Rad pokušava da prepozna modele kojim arhitekta "čita" ili usvaja filozofske pojomove, kao i mehanizme pomoću kojih ih uvodi na scenu sopstvenog diskursa. Delez upozorava da onaj koji stvara (npr. arhitekta) mora biti oprezan prema opštim pojmovima, jer su oni najrigidniji i najnezanimljiviji, predstavljeni kao večne forme ili vrednosti. Arhitektura se prema ovom upozorenju ne sme zadovoljiti čak ni u oblastima kritike i istorije pretresanjem gotovih starih pojmova kao "kostura koji treba da zastraše svako stvaranje". ${ }^{44}$ Istorija svakog diskursa nezanimljiva je, ako sebi ne da u zadatak da "razbudi uspavani pojam, da ga vrati u igru na novoj sceni, makar po cenu da ga okrene protiv njega samog." ${ }^{45}$ Od proizvodnje ili slobode produkcije koju umetnička pozicija nudi, do načela razloga koje se pojavljuje u filozofiji, jedini autentičan put je - kontingentnost. "Tačno je da na putu koji vodi onome što treba misliti sve počinje od čulnosti. Od onog intenzivnog do mišljenja, mišljenje nam se uvek događa posredstvom nekog intenziteta. Prednost čulnosti kao izvora pojavljuje se u sledećem: ono što nagoni na osećanje i ono što se može samo osetiti, jesu jedna ista stvar u susretu, iako su obe istance različite u drugim slučajevima." ${ }^{46}$ Kontingentnost predstavlja načelo slučajnosti i zavisnosti, koje vodi istoriju, a po Delezu istorije nema kao opšte, već samo kao istorije slučajnosti i zavisnosti. Pokušaji da se znanje razvije iz projektantskih postupaka, danas su najprivlačniji upravo arhitektama koji su svesni da se kroz set postupaka koje projektovanje zahteva, formira posebna platforma znanja, znanja koja su različita po vrsti u odnosu na logička znanja, ali koja i njih uključuju, i koja objedinjuju znanja iz različitih diskursa u činu stvaranja, kroz sam akt proizvođenja. Projektovanje kao proces zahteva raznovrsne akcije, aktove, aktivnosti, pa se pojavljuje pitanje da li je moć kontrole nad ovim postupcima u njihovoj organizaciji predmet proučavanja, ili postupci sami predstavljaju vid proučavanja. Istražujući koliko je

44 Delez i Gatari, Šta je filozofija?, 106.

45 Delez i Gatari, Šta je filozofija?, 106.

46 Žil Delez, Razlike i ponavljanja (Beograd: Fedon, 2009), 239. 
moguće kontrolisati proizvod ako kontrolišemo organizaciju postupaka koji do proizvoda vode, projektantske strategije su "utemeljene u poteškoći - na objektivizaciji indirektnih odnosa, koji pronalaze svoj značaj u objektivizaciji neizvesnih budućnosti i u ideji idealizacije korisnika." ${ }^{77}$

U potrazi za onim što struktura može da znači, u odnosu na to kako se pojavljuje/materijalizuje ili kako radi, razvijaju se projektanstske strategije koje eksperimentišu sa arhitektonskim sadržajem od konceptualnih - papirnih projekata, do realizacija koje nedvosmisleno podkopavaju i formu i funkciju, u nadi da će ogoliti značenje. Kroz rane radove dekonstruktivističkih arhitekata istražuju se pristupi koji negiraju funkcionalnost i potkopavaju stabilnost forme (u radovima arhitekata Bernara Čumija, Pitera Ajzenmana i Zahe Hadid). Neposredno nakon destabilizovanja forme, razvijaju se strategije koje formu negiraju i traže postupke dematerijalizacije forme zarad njenog ispunjenja smislom. Pluralnost pristupa kojima se arhitekte druge polovine dvadesetog veka koriste, ne govore o proizvoljnosti potrage, već o izvesnoj odgovornosti u preuzimanju rizika za promenu arhitektonske paradigme. Obavezan da nakon analize konteksta, nakon uvida u postojeći set informacija i činjenica, uočeno protumači i obradi, arhitekta svoj mentalnofizički aparat mobiliše do te mere da savladava upravo pomenutu kontingentnost uslova koji čine arhitektonski kontekst. Oslobođen objektivizacije i racionalizacije kao ispravnih postupaka, arhitekta složenošću svojih racionalnih i intuitivnih znanja, želja i sposobnosti, zapravo ne daje prikaz konteksta već ga konsturiše kroz preduzimanje akcije. Time je čitav postupak aktivan i produktivan, a ne pasivan i opisan. Budući da je realnost prema Delezu u stanju fluksa ili diferencijacije, njena fiksiranost ili identitet ukazuje se samo kao iluzija u određenom momentu. Ovim otkrivanjem konstantne promene iza svakog (prividno) statičnog stanja stvari, autor nas oslobađa obaveze da dajemo odgovarajuće rešenje na odgovarajući problem, već se autentičnost delovanja ka svetu obezbeđuje udruživanjem sa njim, upuštanjem u proces diferencijacije imanentan realnosti koju dokučujemo.

Odjeci ovoga misaonog modela u arhitektonskoj projektantskoj praksi pronalaze se u naporima da se otkriju nagomilani (postojeći) slojevi materije ${ }^{48}$, koji već bar deceniju predstavljaju aktuelnu projektantsku paradigmu. Paradigma udruživanja sa postojećim materijalom jedinstvena je na konceptualnom planu ali se pokazuje kroz savremenu pluralnost stilova u kojima se ovi napori formulišu. Od tema koje obeležavaju arhitektonska bijenala, pa sve do pojedinačnih arhitektonskih praksi nagrađenih najvišim nagradama za arhitekturu u toku protekle decenije, (Cambridge and Massachusetts: The MIT Press, 1992), 153. 
potraga za aktivnom upotrebom nasleđenog ("prošlosti") predstavlja osnovno interesovanje projektantskog diskursa.

Postoji trenutak u razvoju arhitektonskih i filozofskih teorija gde se njihov dodir ostvario na tako direktan način da je u procesu promišljanja i projektovanja došlo do zamene uloga arhitekte i filozofa. Taj susret dogodio se između arhitekte Pitera Ajzenmana i filozofa Žaka Deride, na projektu za park La Vilet, na poziv arhitekte i teoretičara arhitekture Bernara Čumija. Arhitekt i filozof mislili su i crtali 1987. godine projekat Hora (Chora)- projekat savladavanja jednog dela pejzaža parka LaVilet u Parizu. Ovaj susret nije jedini, ali je za savremenu teoriju arhitekture, referentan za razmatranje aktuelnog odnosa arhitekture i filozofije. Do moderne $\mathrm{u}$ arhitekturi kao i tokom nje, arhitektonska teorija predstavljala je prvenstveno skup uputstava za manipulaciju elementima arhitektonske forme i organizacionim modelima prostora (od Albertijevih $10 \mathrm{knjiga}$ o arhitekturi do pet Korbizijeovih arhitektonskih postulata moderne arhitekture), u cilju približavanja idealima propisanim konsenzusom o etici, estetici i tehnici koji je uspostavljen kroz samu tradiciju discipline. Nakon moderne, dolazi do generalnog otvaranja teorijskog diskursa u nekoj vrsti istraživanja koliko se disciplini samoj može prići spolja, van nje. Sami arhitekti, željni oslobađanja od preovladavajućih dogmi, istupaju ka drugim diskursima pronalazeći u njima mogućnosti za promišljanje arhitektonskih problema. Tako ovaj susret, iako ne jedini, postaje referentan za otvaranje novog produktivnog poglavlja odnosa $\mathrm{u}$ kojem se u filozofskim teorijama pokušava pronaći građa za koncipiranje novog arhitektonskog viđenja sveta.

Pomenuti susret filozofa i arhitekte, desio se povodom ideje o dekonstukciji, čiji je arhitekta zapravo filozof, ${ }^{49}$ a koju je arhitekta promišljao kroz koncipiranje arhitekture. Nakon klime dogmatizma koja je kolateralno pratila modernističke ideje, posezanje za dekonstrukcijom značilo je oslobađanje od modela - kakvi god oni bili. To oslobađanje bilo je do te mere zavodljivo, da je dekonstruktivistička misao prirodno skliznula $\mathrm{u}$ arhitekturu, gotovo kroz nivo asocijacija, bez dubljeg ulaženja u razumevanje ove filozofske postavke. Transponovana ponekad proizvoljno, u zanosu dekonstruktivističkog potkopavanja, arhitektura je ovu misao interpretitala od čisto estetske razgradnje forme do negiranja njene strukturalnosti; kroz rastavljanje strukture na elemente i njihovo sastavljanje tako da simuliraju nestabilnost. Na taj način nastalo je slabo mesto odnosa pomenuta dva diskursa, i mesto najdirektnije kritike dekonstrukcije u arhitekturi - kao stilskog pravca. Nepodudarnost u prenošenju koncepta iz filozofskog u arhitektonski diskurs, svakako podleže kritici, ali istovremeno za teoriju arhitekture predstavlja mogućnost za razumevanje složenosti ovog odnosa, gde se direktne analogije pokazuju nemoćnima da obave interdiskurzivnu razmenu znanja. 
Kada govorimo o uticaju filozofskih teorija na teoriju arhitekture a ne o njenom oslikavanju ili ilustrovanju kroz arhitektonsku formu, možemo izdvojiti dve najznačajnije arhitektonske epistemologije u kojima se može pratiti trag upliva filozofskih ideja na projektantske strategije. To su teorije i strategije arhitekata i teoretičara arhitekture: Bernara Čumija i Pitera Ajzenmana, koje reaguju na koncepte koje razvijaju Žak Derida i Žil Delez. Iako su obe epistemologije projektovanja vitalne i menjaju se kroz vreme, rad se zaustavlja na identifikaciji modifikacija koje znanje doživljava u interdiskurzivnoj razmeni, krećući se od filozofke postavke Žila Deleza ka projektantskim strategijama Pitera Ajzenmana.

Konceptualnu podudarnost arhitektonskog prostora i događaja, uvodi u svojoj epistemologiji projektovanja Bernar Čumi, i ona dalje postaje jedna od najuticajnijih teza savremene arhitektonske teorije. Nekoliko decenija kasnije prostor se više i ne vidi osim kao mogućnost da se u svakom sledećem momentu ispuni novim sadržajem. ${ }^{50} \mathrm{O}$ nepodudarnosti koncepta prostora od strane arhitekte i iskustva prostora od strane korisnika, govori i Piter Ajzenman. Prema Ajzenmanu, za filozofa je teško da govori o arhitekturi (kako sam kaže da je otkrio u saradnji sa filozofom Žakom Deridom), a posebno je teško za arhitektu da "filozofira i psihologizira". ${ }^{51}$ No ova poteškoća ne oslobađa arhitektu obaveze organizacije mišljenja zarad strukturiranja relevantnih ulaznih podataka u proces projektovanja što pripada filozofiji, kao ni obaveze analize iskustva prostora od strane korisnika, što pripada psihologiji. Epistemologija projektovanja oba teoretičara i arhitekta - $\breve{C u-~}$ mija i Ajzenmana bazira se na novom odnosu ka racionalnom rezonovanju $u$ projektantskom postupku. Ajzenman, posebno na početku svoje karijere (kasnije menja poziciju i to otvoreno priznaje), veruje da je arhitektonsko projektovanje kao postupak moguće u potpunosti intelektualizovati. S druge strane, Čumi čiji je osnovni interes neuhvatljivost i višeznačnost iskustva prostora, iako završava dokumentovanjem racionalnih teza o prostoru, zapravo veruje $\mathrm{u}$ iracionalnost doživljaja kao osnove za delovanje u polju arhitekture, i na taj način favorizuje destabilizaciju racionalističkog aparata kao model za stvaranje.

Fokusirajući se na dve najuticajnije epistemologije, možemo prepoznati da kao teorijski model za promišljanje odnosa modaliteta mišljenja i modaliteta stvaranja Čumi nudi model paradoksa, a Ajzenman gradi model problematizacije. Problematizacija kao model za promišljanje nije Ajzenmanov izum jer ga, kako sam priznaje, pozajmljuje od Deleza. Tumačeći ga subjektivno, on ga pak pretvara u moćno

50 Vajdler prostor naziva "stanjem spremnosti da se popuni novim sadržajem svakog momenta" u Anthony Vidler, The Architectural Uncanny, (Cambridge and Massachusetts: The MIT Press, 1992), 182.

51 Peter Eisenman, "Making the Cut", in Anytime, ed. Cynthia Davidson, (New York: Anyone Corporation, 2001), 261. 
oružje u savladavanju savremenog projektantskog konteksta. Ajzenman kaže da arhitektura može ponuditi neku vrstu događaja u kojoj je interpretacija okruženja problematizovana. ${ }^{52}$ Pod pojmom okruženje arhitekta ovde podrazumeva sve konkretne uslove na koje projekat odgovara, a nudi mehanizam kojim arhitektura koncipira događaj koji interpretira kontekst tako što ga problematizuje. $\mathrm{Na}$ ovaj način arhitekta razvija novo razumevanje arhitekture i njenih relacija ka drugim diskursima. Pomeranje od problema koji traže rešenje, ka problematizaciji možemo prepoznati kao jasno rezoniranje filozofskih koncepcija Žila Deleza u polju arhitektonskog projektovanja. Svest da izvesni problemi nemaju jednoznačno i fiksno rešenje, već da moraju postati deo kreativnog procesa, eksplicitno je deluzijanska.

Prepoznavanje da nedeterminisanost odnosa između ideja i uslova u odnosu na koje one nastaju, mora biti izražena i arhitekturom, omogućava Ajzenmanu da razvije prepoznatljivu teorijsku platformu u kojoj se ključne ideje konteksta uključuju, odnosno artikulišu i prikazuju kao deo uslovnog rešenja. Bitno je da se u ovom aktiviranju, činioci konteksta nikako ne uokvire i izoluju, nego privremeno modulišu, da bi se ostvarila kontinualna varijacija materije (Delez) od prirodnog do stvorenog, od zatečenog do nadograđenog, od situacije do intervencije. Time Ajzenman razvija svoje viđenje arhitektonskog savijutka (fold) i događaja (event) kroz otkrivanje i aktiviranje koncepata konteksta u odnosu na filozofsku teoriju na koju se oslanja. Njegova epistemologija razvija pristup kojim se formira apstraktno oruđe razmene između uslova konteksta i arhitektonske forme, koje Ajzenman naziva indeksom. Pod uticajem ideja Čarlsa Sandersa Pirsa, koji u lingvistici razvija teorije indeksikalnog ponašanja (indexical behavior) da bi prikazao izvesno stanje, arhitekta indeksikalnošću naziva pristup u kojem se ugrađuje istorija konteksta u arhitektonski projekat, ne prenošenjem, naracijom ili analogijom, već apstraktnim mrežama mentalnih konstrukata koji proizilaze iz konkretnih uslova lokacije. Ovaj pristup podrazumeva reverzibilan i interaktivan odnos gradivnih jedinica konteksta i šupljina među njima, koje nastanjuje arhitektura. Uz pomoć indeksa koje razvija, Ajzenman pokušava da ugradi prošlost $\mathrm{u}$ aktuelno urbano tkivo, bez nostalgije $\mathrm{i}$ naracije, već putem prepoznavanja apstraktne istorijske mreže koju je moguće aktivirati na novi način i tako obezbediti kontinuitet intenziteta u prelazu iz prošlog ka budućem.

Arhitekta ovim reaguje na dominantnu tezu postmodernizma koja modernu vidi kao proizvodnju diskontinuiteta pozadine (tla) i figure (objekta) gde tlo postaje tabula rasa u ime funkcionalizma i antiistorijskih (avangardnih, radikalnih) estetskih principa. U isto vreme reaguje i na površnost postmodernog kontekstualnog pristupa gde se doslovnim citiranjem ili kolažiranjem samo utvrđuje i 
ponavlja ograničen set istorijskih odnosa, kojima nema mesta u novim uslovima. Fiksiranje postojećih odnosa jednako inhibira kompleksnost koliko i modernistička politika čišćenja i zamenjivanja. Nasuprot citiranju, pojavljuje se zahtev za prepoznavanjem nasleđenih sistema i njihovim mutiranjem u novim uslovima, tako da istinsko razumevanje vrednosti istorijskih kako formi tako i misaonih osnova omogućava aktiviranje tih vrednosti u savremenom trenutku u novim (odgovarajućim) oblicima.

Arhitekta Ajzenman na ovaj način traži mogućnost za prikazivanje višestrukosti savremenog života. ${ }^{53}$ Filozofske teorije druge polovine prošlog veka, izgradile su intelektualnu klimu milenijumskog prelaza u kojoj arhitekte iznalaze nove odnose prema tradiciji i istoriji, izbegavajući rehabilitaciju tradicije. Piter Ajzenman utire put nizu projektantskih strategija (u poslednjih par decenija), koje prepoznavanje postojećeg vide kao projektantski čin. Ovom nizu pripada i strategija arhitekte Žana Nuvela koji istražuje tezu da je "arhitektura uvek u odnosu na nešto postojeće. ${ }^{54}$ Nastaje serija aktuelnih arhitektonskih delovanja koja intervencije svode na minimum direktim izlaganjem uočenog postojećeg (kao što to, na primer, čini francuski autorski tim Periferik u projektu Ružičasti Duh / Periferique: Pink Ghoast). Sa istim ciljem, sa druge strane, nastaju projektantske strategije (poput one čiji je autor Su Fuđimoto) koje pokušavaju da stvore strukture na principu kontinualnih funkcionano nedeterminisanih pejzaža, u kojima će svaki korisnik prepoznati i sebi prisvojiti (upotrebiti) mesto. Istorija ovde dolazi sa korisnikom koji je dodeljuje neutralnom pejzažu čiji je mehanizam nedovršenost. Time se kreativni postupak delimično pretače sa autora na konzumenta. Ideja se dovršava u interakciji, pa proizvod nastaje tek uključivanjem i delovanjem publike/ konzumenta.

Postmoderna arhitektura zagovara regeneraciju i fokusira se na ponavljanje (reprezentaciju gotovih prošlih formi), koji u novim uslovima uvek gube originalnu energiju i socijalni kontinuitet, budući da se uzroci prošlih formi ne sadrže u samom citatu. Teškoća da se otkriju elementi postupka projektovanja koji omogućavaju ugradnju pomenute energije u novi prostor, kao i mogućnost da se interpretira prepoznati mehanizam u savremenim uslovima, predstavlja sponu Ajzenmanove teorijske misli i projektantske prakse. Tenzija koju objekat arhitekture kreira unutar urbanog konteksta, kompleksna je i ne tiče se samo pomenutog odnosa figure i tla već promenljivosti socijalnog konteksta unutar kog se formiraju odnosi figura-tlo. Ajzemnan uočava kako u novim uslovima komunikacije informatičkog društva kreacije neizostavno paradoksalan i problematičan. Videti opširnije u James Williams, "Deleuze's Ontology and Creativity: Becoming in Architecture", Pli - The Warwick Journal of Philosophy, No 9 Parallel Processes: Philosophy and Science (2000):200-219 
objekti nisu toliko bitni koliko vremenski događaji. Da bi nepredvidivost ugradio u arhitekturu, arhitekta zamagljuje prostorne i vremenske podele na tlo i objekat, staro i novo, želeći da proizvede nerazgovetnost u percipiranju elemenata projekta. Novo tako postaje razumljivo kao nešto van fokusa u odnosu na ono što već postoji. Ovo stanje van fokusa, nasuprot fundamentalnom odvajanju od postojećeg, poseduje mogućnost zamagljivanja i izmeštanja celine, koja je i staro i novo istovremeno. ${ }^{55}$ Decentriranost kao model kojim se arhitektura pozicionira u razumevanje konteksta, da bi se proizvelo novo ugrađeno u postojeće, je model koji arhitekta Ajzenman ispituje u radu na svojim aktuelnim projektima. U svojoj dugoj karijeri, Piter Ajzenman balansira između umetničkog i intelektualnog karaktera projektantskog diskursa, krećući se između fenomenološkog, fizičkog i afektivnog. $\mathrm{Na}$ početku karijere, arhitekta se bavi egzistencijalnim konceptima prisustva, interiornosti i treće aure (u zbirci eseja Inside Out), nudeći da arhitekturu transformiše od umetničke $u$ intelektualnu disciplinu. Inspirišući se kulturnim temama, svoje filozofske težnje fokusira na otkrivanje kako projektovati kritičku arhitekturu. Od promišljanja pojmova čvrstog, praznine, pomaka, smicanja prisustva/odsustva, decentriranja, Ajzenman se kreće ka umetničkom aspektu diskursa, oslanjajući se pre na pojezis nego na intelekt. Završavajući u gotovo ezoteričnim konceptima tragova i katakreze (gde se bavi upotrebom reči u značenju koje one zapravo nemaju), Ajzenman ispituje arhitekturu u odnosu na jezik, ali ne kao jezik, nego kao $\bmod$ pisanja.

Mogućnost da se problematizacija kao pristup, razlika kao jedinica sadržaja (kvantum) i kreacija kao akt povežu u reakciji na sveobuhvatni haos u koji smo uronjeni, jeste posebna definicija događaja kod Deleza koja u arhitekturi odzvanja kroz epistemologiju Pitera Azenmana. ${ }^{56} \mathrm{U}$ odnosu na sopstveno razumevanje definicije događaja Žila Deleza, Ajzenman koncipira projektantsku strategiju kontra-ostvarivanja, gde ograničenja lokacije vidi kao njihove singularitete ili one koji čine njegov intenzitet. Upravo ograničenjima se dalje može manipulisati (preusmeravati i modifikovati) u projektantskom postupku, tako da stavljajući ih $u$ pokret, arhitekta ih povezuje sa idejama o prostorno-vremenskom kontinuitetu upotrebom savremenih medija. Arhitekta u susretu sa nekim ograničenjem lokacije, u njemu prepoznaje sigurno mesto i konačno iskustvo, odnosno ono što daje identitet datom okruženju. Transformacijom i razvodnjavanjem tog jasnog doživljaja (koje uključuje objekat i tlo, arhitekturu i prirodu, prostor i vreme) u repeticiju oblika i tema, čuva se ono što daje identitet posmatranom okruženju, ali u postupku postajanja, kretanja i promene. Na ovaj način, arhitekta elaborira promišljanje

56 od urbanističkog plana (Rebstock) za Frankfurt, preko Paviljona-autobuske stanice u Berlinu, do Grada kulture u Galiciji 
prostora kroz iskustvo postajanja, povezanosti i destrukcije identiteta. ${ }^{57}$ Filozofske ideje o temeljnosti destrukcije fiksnih identiteta, intenzitetu postajanja ili rasprostiranju veza Ajzenman ugrađuje u tkivo svoje arhitekture, jednako kroz istraživanje forme ili konteksta koliko i kroz strukturu programa ili odnos prema sadržaju, tamo gde programa i nema.

\section{Zaključna razmatranja}

Uspostavljanje produktivnih odnosa između filozofije i arhitekture, kojima se razvijanjem filozofskih koncepata grade novi okviri za razmišljanje o arhitektonskim problemima, a u okviru kojih specifičnosti arhitektonskih znanja i veština mogu uticati na formiranje novih filozofskih koncepata, interes je ovog rada $u$ cilju ispitivanja mogućnosti generisanja novih metodoloških modela projektovanja na osnovu interdiskurzivne razmene znanja. Filozofska teorija Žila Deleza, ostvarila je uticaj na arhitektonsko projektovanje na mnogo različitih nivoa: od ilustracija novouspostavljenih pojmova arhitektonskom formom, privilegovanja procesa u odnosu na proizvod, preko analogija apstraktnih filozofskih mehanizama i arhitektonskih organizacionih modela, do produbljivanja pitanja same arhitekture u odnosu na filozofske probleme i uspostavljanja platforme filozofije arhitekture.

Rad prepoznaje mehanizme razmene znanja između filozofskog i arhitektonskog diskursa oslanjajući se na principe ispitivane filozofske teorije. Kao najautentičniji mehanizam razmene pokazuje se nestrukturirano izlaganje znanjima i praksama obe discipline, gde će se omogućiti materijalno rezoniranje intenziteta. Tek ovo rezoniranje dalje u sopstvenim poljima formuliše ideje, koncepte $\mathrm{i}$ činove. Identifikovanjem novih projektantskih epistemologija nastalih pod uticajem izlaganja teorijama filozofskog diskursa, ovaj rad pokušava proširiti polje mogućnosti za kreativno ponašanje $\mathrm{u}$ arhitektonskom projektovanju. Kao konktetan zaključni stav, rad prepoznaje dva koncepta koje je moguće uvesti u obliku intenziteta u tkivo arhitektonskih znanja i posledično projektantskih metodologija. To su koncepti problematizacije i decentriranja koje studija trasira kroz teorijski i praktičan rad arhitekte i teoretičara arhitekture Pitera Ajzenmana, ali koji istovremeno predstavljaju takozvani otvoreni kraj delezovske rizomske strukture promišljanja koju rad usvaja. Kao što je istaknuto u prethodnim poglavljima, otvorenost je osnovna karakteristika ispitivane filozofske platforme i upravo nju rad koristi u prepoznavanju dodira filozofije i arhitekture kroz rad arhitekte Ajzenmana, ali što je još značajnije, taj dodir nudi kao klicu za razvoj novih metodoloških modela. Diferencijaciju polja mogućnosti koje pripada arhitektama prema delezovskom 
scenariju, ovaj rad nudi kroz formiranje novih projektantskih metodoloških modela na konkretnim smernicama dve ekstrahovane klice pod nazivom problematizacija i decentriranje koje imaju potencijal za dalji razvoj ka nepoznatom.

$\mathrm{Na}$ ovaj način arhitektonsko projektovanje bi bilo moguće istraživati kao jedan od oblika deluzijanskog otpora ka fiksiranosti i zatvorenosti racionalističkih uverenja, i mogućnost da se konačno "svetu donese nešto u potpunosti nerazumljivo." 58

\section{Milena Kordić}

Univerzitet u Beogradu - Arhitektonski fakultet

\section{Literatura}

Blagojević, Ljiljana. "Dekonstruktivistička arhitektura n'existe pas" u Glas i pismo, Žak Derida u odjecima, priredio Petar Bojanić. Beograd: Disput, Institut za filozofiju i društvenu teoriju, 2005. 89-97.

Borden, Iain and Rendell, Jane, edited by. InterSections: Architectural Histories and Critical Theories. London: Routledge, 2000.

Broadbent, Geoffrey and Ward, Antony. Design methods in architecture. London: Lund Humphries for the Architectural Association, 1969.

Cross, Nigel. Design Thinking. New York: Berg, 2011.

De Landa, Manuel. "Deleuze and The Use of Genetic Algorithms in Architecture" in Architectural Design: Contemporary Techniques in Architecture, edited by Ali Rahim, Vol. 72. Wiley Academy Press, January 2002. 9-13.

Eisenman, Peter. Diagram diaries. New York: Universe Publishing, 1999.

Eisenman, Peter. "Making the Cut" in Anytime, edited by Cynthia Davidson. New York: Anyone Corporation, 2001.

Eisenman, Peter. "Unfolding events: Frankfurt Rebstock and the possibility of a new urbanism" in Unfolding Frankfurt edited by Eisenman, Rajchman, Geib and Kohso. Berlin: Ernst \& Sohn, 1991.

Hays, Michael, edited by. Architecture Theory since 1968. (1998.) Cambridge and London: The MIT Press, 2000.

Jobst, Marko. "Why Deleuze, Why Architecture" in Deleuze and Architecture, edited by Helene Frichot and Stephen Loo. Edinburgh University Press, 2013.

Jones, John Chris. Design Methods, (1970) 2nd ed. London: John Wiley \& Sons, 1992. 
Kipnis, Jeffrey. "Towards New Architecture" in Folding in Architecture. (1993.) England: AD, Wiley-Academy, 2004. 57-65.

Kipnis, Jeffrey. "Forms of Irrationality" In Strategies in Architectural Thinking. edited by Whiteman, Kipnis and Burden. Cambridge, Massachusettes and London: The MIT Press, 1992.

Leach, Neil edited by. Rethinking Architecture, A reader in Cultural Theory. London: Routledge, 1997.

Nuvel, Žan i Bodrijar, Žan. Singularni objekti - arhitektura i filozofija. Zagreb: AGM, 2008.

Ryle, Gilbert. The concept of Mind. London: Hutchinson, 1949.

Tschumi, Bernard. "Questions of Space: The Pyramid and the Labyrinth or the Architectural Paradox" in Studio International, Vol. 86. Sept-Okt, 1975. 136-142.

Tschumi, Bernard. Arhitektura i disjunkcija. Zagreb: AGM, 2004.

Till, Jeremy. Architecture depends. London:The MIT Press, 2009.

Vidler, Anthony. The Architectural Uncanny: Essays in the Modern Unhomely. Cambridge and London: The MIT Press, 1992.

Wrigley, Mark. The Architecture of Deconstruction: Derrida's Haunt. Cambridge and London: The MIT Press, 1995.

Badiou, Alain. Deleuze: The Clamor of Being (1997). Traslated by Louise Burchill. London and Minneapolis: University of Minnesota Press, 2000.

Ballantyne, Andrew. Deleuze and Guattari for architects. London: Routledge, 2007.

Delez, Žil i Gatari, Feliks. Šta je filozofija?. Novi Sad: IK Zorana Stojanovića, 1995.

Delez, Žil. Pokretne slike. Novi Sad: Izdavačka knjižarnica Zorana Stojanovića, 1998.

Delez, Žil. Razlike i ponavljanja. Beograd: Fedon, 2009.

Deleuze, Gilles and Guattari, Felix. A Thousand Plateaus:Capitalism and Schizophrenia (1980), translated by Brian Massumi. Minneapolis and London: University of Minnesota Press, 1987, 11th print 2005.

Deleuze, Gilles. What is the Creative Act? Predavanje na konferenciji Conference donnee dans le cadre des "Mardis de la Fondation," 17. mart 1987. http://www.youtube.com/ watch? $\mathrm{v}=7$ DskjRer95s (pristupljeno 22.5.2013.)

Grosz, Elizabeth. Architecture from the Outside: Essays on Virtual and Real Space. Cambridge: The MIT Press, 1995.

Grosz, Elizabeth. Chaos, Territory, Art: Deleuze and the Framing of the Earth. New York: Columbia University Press, 2008.

Ian Buchan, edited by. A Deleuzian century?. USA: Duke University Press, 1999.

Platon. Teetet. Prevod: Milivoj Sironić. Zagreb: Naprijed, 1979.

Rajchman, John. Constructions. Cambridge and London: The MIT Press, 1998.

Rajchman, John. The Deleuze Connections. Cambridge and London: The MIT Press, 2000.

Žižek, Slavoj. The Reality of the Virtual. London: decembar 2003. http://www.youtube.com/ watch?v=RnTQhIRcrno (pristupljeno 12.12.2013.)

Žižek, Slavoj. Organi bez tela. Beograd: Centar za medije i komunikacije, 2012. 
Williams, James. "Deleuze's Ontology and Creativity: Becoming in Architecture" in Pli The Warwick Journal of Philosophy, No 9, Parallel Processes: Philosophy and Science. Warwick, 2000. 200-219.

Williams, James. Gilles Deleuze's Logic of Sense: A Critical Introduction and Guide. Edinburgh University Press, 2008.

\section{Milena Kordić}

\section{Epistemology of Architectural Design From Interdiscursive Knowledge Exchange to Design Strategy}

(Summary)

Tracing the influence of philosophical theories on architecture, the paper explores possibilities to expand the theoretical platform that allows for creation of new design methodological models. If, as a contemporary cultural context, we assume the shift in understanding of the world from determined and rational to multiple, temporal, and complex, then the (architectural) design models are moving from static and fixed to balanced dynamic systems. In such dynamic systems, order and disorder are pulsing toward each other continuously. In this paper, the transformation of existing to new design methodological models are investigated on an example of resonance of Gilles Deleuze's philosophical ideas and thought-creative models of architect and theorist Peter Eisenman. Identifying the formative conditions for design methodology models, the paper introduces an open-end in the design methodology structure, from which the emergence of new creative models is possible.

KEY WORDS: thought model, creative model, interdiscursive knowledge exchange, epistemology of design, design strategy. 